\title{
MANAJEMEN PEMBELAJARAN DI MIS HIDAYATUL INSAN PALANGKA RAYA Learning Management at MIS Hidayatul Insan Palangka Raya
}

\author{
*Muhammad Tri Ramdhani \& Istiqlaliyah \\ Islamic Education Study Program, Universitas Muhammadiyah Palangkaraya, RTA Milono St. Km.1,5 \\ Palangka Raya, Indonesia \\ *e-mail : $\underline{\text { muhammadtriramdhani@gmail.com }}$
}

\begin{abstract}
ABSTRAK
Manajemen pembelajaran dapat diartikan sebagai usaha untuk mengelola sumber daya yang digunakan dalam pembelajaran sehingga tujuan pembelajaran dapat dicapai secara efektif dan efisien. Pemilihan model pembelajaran yang tepat akan sangat menentukan minat, partisipasi peserta didik, dan akan meminimalisir problematika yang dihadapi guru dalam pembelajaran. Pada bidang pembelajaran diharapkan guru dapat memanajemen pembelajaran dengan menentukan model pembelajaran yang tepat sehingga dapat menarik minat peserta didik terhadap materi pelajaran. Manajemen pembelajaran di MIS Hidayatul Insan Palangkaraya meliputi persiapan, pelaksanaan, dan evaluasi. Permasalahan yang di hadapi guru di MIS Hidayatul Insan Palangkaraya, yaitu permasalahan bagaimana menanamkan konsep yang sama pada peserta didik. Salah satu cara guru mengatasi hal tersebut ialah dengan memberikan contoh yang mudah agar peserta didik bisa mengerti. Setelah melakukan beberapa persiapan dan melaksanakan pembelajaran guru melakukan evaluasi memberikan tugas kepada peserta didik.
\end{abstract}

Kata kunci: Manajemen, Pembelajaran

\begin{abstract}
Learning management can be interpreted as an effort to manage the resources used in learning so that the learning objectives can be achieved effectively and efficiently. Selection of appropriate learning model will determine the interest, participation of learners, and will minimize the problems faced by teachers in learning. In the field of learning is expected teachers can manage learning by determining the appropriate learning model so as to attract learners' interest on the subject matter. The learning management at MIS Hidayatul Insan Palangkaraya includes preparation, implementation, and evaluation. Problems faced by teachers in MIS Hidayatul Insan Palangkaraya, the problem of how to instill the same concept in learners. One way teachers overcome this is to provide an easy example so that learners can understand. After doing some preparation and carrying out the learning the teacher performs the evaluation assigning the task to the learners.
\end{abstract}

Keywords: Management, Learning

\section{PENDAHULUAN}

Undang-undang No 14 tahun 2005 dan Permendiknas No 16 tahun 2007 menyatakan bahwa sebagai sebuah profesi, guru dituntut untuk memiliki memiliki empat kompetensi yaitu kompetensi pedagogik, kepribadian, sosial, dan profesional. Kompetensi pedagogik adalah kemampuan mengelola pembelajaran peserta didik. Sedangkan kompetensi kepribadian adalah kemampuan kepribadian yang mantap, berakhlak mulia, arif, dan berwibawa serta menjadi teladan peserta didik. Adapun kompetensi profesional adalah kemampuan penguasaan materi pelajaran secara luas dan mendalam. Selain itu, kompetensi sosial adalah kemampuan guru untuk berkomunikasi dan berinteraksi secara efektif dan efisien dengan peserta didik, sesama guru, 
orangtua/wali peserta didik, dan masyarakat sekitar.

Suatu pembelajaran akan ideal apabila keempat kompetensi tersebut terintegrasi dalam kinerja seorang guru. Pembelajaran bukan hanya sekedar menekankan kepada pengertian konsep-konsep belaka, tetapi bagaimana melaksanakan proses pembelajarannya dan meningkatkan kualitas proses pembelajaran tersebut, sehingga pembelajaran tersebut menjadi bermakna. Terkait dengan kemampuan mengelola pembelajaran peserta didik (kompetensi pedagogik) inilah guru berkepentingan untuk melakukan manajemen pembelajaran. Untuk memiliki kemampuan mengelola pembelajaran (kompetensi pedagogik) dengan baik, tentu saja guru perlu memahami unsur-unsur penting yang berkaitan dengan manajemen pembelajaran.

Setiap individu juga mempunyai keunikan masingmasing, mempunyai kemampuan dan karakteristiknya masing-masing. Mulai dari yang cepat memahami pelajaran, hingga yang lamban. Mulai dari peserta didik yang berprestasi, hingga peserta didik yang sarat akan masalah. Hal tersebut tentunya menjadi permasalahan di Madrasah Ibtidaiyah. Maka dari itu, penulis merasa tertarik untuk meneliti problem-problem apa saja yang dihadapi guru dalam memanajemen sebuah pembelajaran di MIS Hidayatul Insan Palangkaraya

\section{METODOLOGI}

Penelitian ini menggunakan pendekatan kualitatif, artinya melalui pendekatan ini diharapkan dapat diperoleh data deskriptif yaitu berupa kata-kata yang berasal dari naskah wawancara, catatan di lapangan dan dokumentasi resmi lainnya. Menurut
Nawawi, dalam hal ini menjelaskan bahwa melalui penelitian kualitatif dapat menghimpun data yang sewajarnya, menggunakan cara yang sistematis, terarah dan dapat di pertanggung jawabkan karena tidak kehilangan sifat dan kealamiannya. Adapun yang menjadi subyek dalam penelitian ini adalah 1 (satu) orang guru wali kelas IV B.

Pada penelitian ini penulis menggunakan beberapa teknik pengumpulan data yaitu observasi, wawancara, dan dokumentasi sebagai teknik pendukung dalam pengumpulan data penelitian. Teknik observasi adalah pengamatan yang dilakukan secara sengaja, sistematis mengenai fenomena sosial dan gejala-gejala psikis untuk kemudian dilakukan peneliti. Adapun wawancara adalah teknik pengumpulan data yang digunakan peneliti dalam bentuk komunikasi antara dua orang, melibatkan seseorang yang ingin memperoleh informasi dari seseorang lainnya dengan mengajukan pertanyaan-pertanyaan, berdasarkan tujan tertentu. Sedangkan dokumentasi adalah cara pengambilan data dari dokumen-dokumen yang dapat dipercaya kebenarannya.

\section{HASIL DAN PEMBAHASAN}

A. Identitas Pendidik (Narasumber/Subjek)

$\begin{array}{ll}\text { Nama } & : \text { Puji Lestari } \\ \text { NIP } & :- \\ \text { Pendidik sebagai } & : \text { Wali Kelas dan Guru } \\ \text { Bidang Studi } & \\ \text { Kelas } & : \text { IV B } \\ \text { Bidang Studi } & : \text { IPA dan Matematika } \\ \text { Lama Mengajar } & : 5 \text { Bulan }\end{array}$

B. Problematika yang Dihadapi Pendidik Menurut Ibu PL, "Permasalahan yang saya hadapi saat ini adalah bagaimana 
menanamkan konsep yang sama pada peserta didik. Jadi, ada masing-masing peserta didik memahami pelajaran dengan konsep yang berbeda. Jadi, sebagai seorang pengajar saya harus bisa menanamkan satu konsep yang sama pada peserta didik. Hal tersebut karena cara penalaran peserta didik yang berbedabeda. Contohnya seperti si A memandangnya seperti ini. Sedangkan si $B$ memandangnya seperti ini. Jadi, saya sebagai pengajar harus memberikan contoh yang mudah agar peserta didik bisa mengerti. Kemudian setelah itu, saya bisa menstabilkan pemikiran peserta didik". Selain itu, menurut Ibu PL, "Peserta didik kadang-kadang tidak terlalu fokus, kurangnya konsentrasi dan ribut pada saat pembelajaran. Faktor tersebut menjadi kendala buat saya karena ketika saya menjelaskan materi pelajaran, disebelah kiri sudah paham. Sedangkan disebelah kanan belum paham". Permasalahan yang di hadapi Ibu PL, yaitu permasalahan bagaimana menanamkan konsep yang sama pada peserta didik. Permasalahan Ibu PL tersebut diatasi dengan menerapkan sebuah cara yaitu memberikan contoh yang mudah agar peserta didik bisa mengerti. Kemudian setelah itu, ibu PL bisa menyamakan pemikiran semua peserta didik. Selain itu, permasalahan lainnya peserta didik kadang-kadang tidak terlalu fokus, kurangnya konsentrasi dan ribut pada saat pembelajaran.

\section{Persiapan Pembelajaran}

Sebelum memulai sebuah proses pembelajaran, ibu PL tentunya melakukan beberapa hal yang harus disiapkan, seperti menyiapkan materi pelajaran, soal-soal sebagai bentuk evaluasi peserta didik. Karena menurut ibu PL, "Mengajar itu gampanggampang susah. Tujuan utamanya agar bisa menjadikan anak-anak yang cerdas". Seperti halnya pada permasalahan yang dihadapi ibu PL di atas, ialah bagaimana menanamkan konsep yang sama pada peserta didik, ibu PL tentunya merasa harus bisa menanamkan satu konsep yang sama pada peserta didik dengan menerapkan sebuah cara yaitu memberikan contoh yang mudah agar peserta didik bisa mengerti.

\section{Pelaksanaan Pembelajaran}

Pada saat proses pembelajaran, ibu PL mengalami beberapa kesulitan. Kesulitankesulitan tersebut ialah peserta didik kadangkadang tidak terlalu fokus, kurangnya konsentrasi dan ribut pada saat pembelajaran. Faktor tersebut menjadi kendala bagi ibu PL karena ketika ibu PL menjelaskan materi pelajaran, disebelah kiri sudah paham. Sedangkan disebelah kanan belum paham.

Adapun proses pembelajaran yang dilakukan oleh ibu PL pada saat dilakukan observasi ialah sebagai berikut.

1. Guru membuka pembelajaran dengan salam.

2. Guru menyampaikan judul materi yang akan dipelajari.

3. Guru menjelaskan materi pelajaran dengan menggunakan metode ceramah dan tanya jawab.

4. Guru memberikan evaluasi berupa tugas kepada peserta didik dengan mendiktekan soal-soal tersebut. 


\section{E. Evaluasi Pembelajaran}

Setelah melakukan beberapa persiapan dan melaksanakan pembelajaran, ibu PL melakukan evaluasi terhadap peserta didik guna untuk mengetahui sejauh mana peserta didik dapat menangkap materi pelajaran yang telah diajarkan. Bentuk evaluasi yang dilakukan ibu PL ialah memberikan tugas berupa soalsoal dengan cara mendiktekannya kepada peserta didik. Kemudian peserta didik menuliskannya dibuku tugas mereka masingmasing.

\section{KESIMPULAN}

Manajemen pembelajaran dapat diartikan sebagai usaha untuk mengelola sumber daya yang digunakan dalam pembelajaran sehingga tujuan pembelajaran dapat dicapai secara efektif dan efisien. Manajemen pembelajaran di MIS Hidayatul Insan Palangkaraya meliputi persiapan, pelaksanaan, dan evaluasi. Permasalahan yang di hadapi guru di MIS Hidayatul Insan Palangkaraya, yaitu permasalahan bagaimana menanamkan konsep yang sama pada peserta didik. Salah satu cara guru mengatasi hal tersebut ialah dengan memberikan contoh yang mudah agar peserta didik bisa mengerti. Setelah melakukan beberapa persiapan dan melaksanakan pembelajaran guru melakukan evaluasi memberikan tugas kepada peserta didik.

Pemilihan model pembelajaran yang tepat akan sangat menentukan minat dan partisipasi peserta didik dalam pembelajaran. Melalui model pembelajaran yang tepat diharapkan peserta didik tidak hanya dapat pengetahuan tentang materi pelajaran yang diajarkan, namun juga memiliki kesan yang mendalam tentang materi pelajaran, sehingga dapat mendorong peserta didik untuk mengimplementasikan konsep nilai-nilai materi pelajaran dalam kehidupan sehari-sehari. Pada bidang pembelajaran diharapkan juga guru dapat memanajemen pembelajaran dengan menentukan model pembelajaran yang tepat sehingga dapat menarik minat peserta didik terhadap materi pelajaran. Sehingga problem-problem yang akan dihadapi guru selama proses pembelajaran juga akan terminimalisir.

\section{DAFTAR PUSTAKA}

Dedy Mulyana. 2003. Metodologi Penelitian Kualitatif. Bandung: Remaja Rosdakarya.

Margono, S. 2003. Metodologi Penelitian Pendidikan. Jakarta: Rineka Cipta.

Moeloeng, Lexi J. 2004. Metodologi Penelitian Kualitatif. Bandung: Remaja Rosdakarya.

Nawawi, HA dan H Mimi Martini. 1994. Penelitian Terapan. Yogyakarta: Gajah Mada Universitas Pers.

Rezeki, Sri, Murniati dan Cut Zahri Harun. Manajemen Pembelajaran Pendidikan dan Pelatihan Prajabatan Pada BKPP Aceh, Jurnal Administrasi Pendidikan ISSN 23020156. Banda Aceh: Pascasarjana Universitas Syiah Kuala.

Rohman, Muhammad dan Sofan Amri. 2012. Manajemen Pendidikan Analisis dan Solusi Terhadap Konerja Manajemen Kelas dan Strategi Pengajaran yang Efektif. Jakarta: Prestasi Pustakaraya.

Saefullah. 2014. Manajemen Pendidikan Islam. Bandung: Pustaka Setia.

Sagala, Syaiful. 2014. Konsep dan Makna Pembelajaran. Bandung: Alfabeta.

Sanjaya, Wina. 2013. Perencanaan \& Desain Sistem Pembelajaran. Jakarta: Kencana Prenadamedia Group. 
Sri Danarwati, Yanti. Jurnal Manajemen Pembelajaran dalam Upaya Meningkatkan Mutu Pendidikan. Solo: STIA ASMI.

Syaifurrahman dan Tri Ujiati. 2013. Manajemen dalam Pembelajaran. Jakarta: Indeks. 